\title{
DEVELOPING PROTOTYPE INDICATORS OF VALUE AND COSTS ADDED THROUGH PUBLIC INVOLVEMENT PROGRAMS
}

\author{
D. Lach \\ P. Hixson \\ M. Silbernagel \\ K. Branch \\ J. Heerwagen \\ J. Bradbury
}

January 1995

\section{Handout}

Prepared for

the U.S. Department of Energy

under Contract DE-AC06-76RLO 1830

Pacific Northwest Laboratory

Richland, Washington 99352

\section{DISCLAIMER}

This report was prepared as an account of work sponsored by an agency of the United States Government. Neither the United States Government nor any agency thereof, nor any of their employees, makes any warranty, express or implied, or assumes any legal liability or responsibility for the accuracy, completeness, or usefulness of any information, apparatus, product, or process disclosed, or represents that its use would not infringe privately owned rights. Reference herein to any specific commercial product, process, or service by trade name, trademark, manufacturer, or otherwise does not necessarily constitute or imply its endorsement, recommendation, or favoring by the United States Government or any agency thereof. The views and opinions of authors expressed herein do not necessarily state or reflect those of the United States Government or any agency thereof. 


\section{DISCLAIMER}

Portions of this document may be illegible in electronic image products. Images are produced from the best available original document. 


\section{ACKNOWLEDGEMENTS}

This research project was made possible through the vision of Lori Ramonas and Steve Stein of the Pacific Northwest Laboratory who were willing to sponsor this research on public involvement. In addition, Lori Ramonas provided additional support of the project through her sponsorship of Peter Hixson, an intern from Syracuse University, who provided much of the legwork needed to get this research done. The interview team of Peter Hixson, Michelle Silbernagel, Lori Ramonas, and Barb Wise collected the original data on which this report is based. And, finally, the original ideas of Kristi Branch and Judith Bradbury guided this project from the beginning. 


\subsection{INTRODUCTION}

As more managers realize that public input in public sector decision making is a given in the current political and social climate, many are turning to public involvement as a way to manage the input so that it is beneficial to their decisions and projects. Public involvement is starting to become a familiar way of doing business for the Department of Energy (DOE) and its contractors. Yet, many, if not most, DOE and contractor managers are still unclear about the value and costs that public involvement can provide to their projects. Proponents claim that public involvement increases the acceptability of project goals by increasing stakeholders' knowledge about and involvement in decisions of impertance to them. In spite of these assertions avowing the benefits of public involvement, proponents have not generated methods that demonstrate or provide evidence of the value added through incorporating public involvement into projects.

As DOE and contract managers are increasingly directed to incorporate public input in their project planning and decision making, questions are beginning to surface about the value and costs of public involvement as a way to manage that input. There is a pressing need to document the value and costs of public involvement for the participants in these processes--the stakeholders--and to present this information to decision makers in a way that helps them assess the value and costs of managing public input through a public involvement program.

Developing a series of indicators to assess the value and costs of using public involvement programs to manage public input in decision making processes involves three basic steps:

(1) identifying the dimensions of public involvement that participants perceive as adding value or costs to projects;

(2) developing ways to measure those dimensions through social indicators and metrics of behavior; and

(3) using the indicators to inform the design of programs that maximize the benefits and minimize the costs to managers of using public involvement.

This research project focuses on the first two steps but offers hints to managers responsible for public involvement program design.

\section{0 RESEARCH OBJECTIVES}

This research effort is designed to develop prototype indicators of the value and costs added to projects by public involvement efforts. The first step towards this objective was to identify the various dimensions of value and costs and to assess how those dimensions are distributed among different participants. Of critical importance during this phase of the research was the documentation of how participants in decision making processes that have included public involvement characterize the value and costs of public involvement.

The next step was to develop a draft series of indicators based on the identified dimensions that characterize the value and costs of public involvement for different participants. The indicators operationalized the dimensions so they could be measured. Indicators of the value added or subtracted by public involvement fall into three categories--process, outcome, and cost. 
The final objective of this project was to produce a list of potential metrics that can be used in future tests to validate the prototype indicators.

\subsection{LITERATURE REVIEW}

We reviewed the public involvement literature in an attempt to identify any existing work on indicators or metrics of public involvement. Because public involvement efforts have only recently been integrated into decision making processes, we did not expect to find a great deal of empirical research on appropriate indicators of value added through public involvement. However, we believed the relevant, related literature would be informative in the protocol development and data analysis.

Our review of the literature revealed that empirical analysis of public involvement processes is in its formative stages. The current literature fits generally into one of two categories: (1) case studies or (2) normative prescriptions of how and why to do public involvement. Case studies generally provide programmatic, evaluative assessments that examine the effectiveness of a public involvement process based on whether or not program goals and objectives were achieved. These studies have limited empirical value in terms of the generalizability of their findings. This type of research is primarily self-referential and as a result does not facilitate comparison across public involvement processes. The second type of public involvement literature focuses on the reasons why and how public involvement processes should be implemented. Consensus building and the fulfillment of democratic principles are often cited as support for public involvement processes. Appendix A lists the literature reviewed.

Both categories of literature, case studies and normative prescriptions, usually provide suggested methods for conducting public involvement. For example, proponents of public involvement advise that all affected stakeholders be identified and asked to participate in public involvement activities so that their concerns and needs can be incorporated into any final decision. Otherwise, they are likely to "ambush" a project, filing legal injunctions or participating in other efforts designed to stop planned activities.

As expected, little documentation of the value or costs actually added through public involvement exists. Nevertheless, the review of existing literature did highlight some of the dimensions of value that appear to be important to stakeholders. Issues of public acceptability, accessibility, good decision making, education and leaming, time commitments, and trust were commonly discussed themes in the extant literature. This information was used to assess the validity of the indicators that were developed through the analysis of data collected in the interviews.

\subsection{METHODS}

As discussed above, the first phase of this research was to identify the various dimensions of value or cost added through public involvement processes. The data used to identify the dimensions were obtained through interviews with the participants of three different DOEsponsored public involvement processes.

\subsection{Protocol Development and Interviews}

The interview protocol progressed through several iterations before advancing to its final version. The protocol used in the interviews is attached as Appendix B. The interview questions focused on three main themes: 
1) Expectations

a) What the participants wanted the public involvement process to accomplish

b) How the participants expected the process to fulfill those expectations

c) Whether the process fulfilled those expectations

2) Benefits and costs of the public involvement process. Issues of public acceptability, project success, and efficiency were also examined.

3) The effect of the public involvement process on decision making.

In an attempt to identify the multiple dimensions of value, the respondents were asked to answer each question in reference to themselves personally, to their organizations, to the project with which they were involved, and to the community. The essence of several questions was quite similar, although the wording of the questions was different. This method of multiple questioning was used in order to ensure that all facets of the different issues were explored.

Interviews were semi-structured, a format which allowed the interviewer to probe for both process responses (articulation of values or costs experienced as a result of participating in the public involvement process) and outcome responses (articulation of values or costs experienced as a result of the specific outcome(s) of the public involvement process). The flexibility of the semi-structured format also helped avoid undue repetition of questions. Interviews were conducted with teams of two interviewers. Audio equipment was not used, however notes were taken during the interviews.

\subsection{Sampling}

\subsubsection{Selection of Public Involvement Programs}

This research focused on three different DOE projects that used public involvement processes:

(1) the VOC Arid ID program;

(2) the Future Sites Working Group; and

(3) the Tank Waste public involvement projects.

Both the Future Sites Working Group and the Tank Waste public involvement projects are completed. The VOC Arid ID is beginning its fourth year of engagement; however, it has completed several phases of its public involvement plan. These projects were selected on the basis of three criterion:

(1) A wide range of stakeholders participated in the public involvement processes. Stakeholders included managers, public involvement practitioners, regulatory agency representatives, technology developers, and public interest group representatives.

(2) The public involvement processes were in different stages of completion when this research was conducted. This variation facilitated the thorough examination of process versus outcome value responses.

(3) The public involvement processes are perceived as successful. Past research indicates that participants of successful processes are more likely to articulate benefits as well as disadvantages of the process in which they were involved than are participants of less successful programs. 
While the projects selected for this research meet these three criteria, several caveats must be noted about the generalizability of the project results to other circumstances. All three DOE projects involved the same or similar types of stakeholders. In fact, many of the respondents interviewed for this project have participated on more than one of the three projects. Most of the respondents were experienced public involvement participants and very familiar with the issues surrounding the individual projects. All three DOE projects involved the same site, Hanford, although the problems addressed in the projects were slightly different. In addition, the problems addressed in the projects have not typically elicited passionate responses or involvement from stakeholders, although respondents consider the problems addressed by the projects to be serious and long-standing. All three projects were viewed by participants and observers as successful, yet none of the projects have implemented any decisions informed by the public involvement process as of the writing of this report.

While project similarity facilitated the analysis of the data collected for this report, it must be remembered that many types of public involvement exist. The dimensions of value identified by participants in these three projects may be limited by the circumstances described above. Care must be taken in generalizing the results from this limited sample to the larger population of public involvement efforts.

\subsubsection{Selection of Respondents}

The sampling strategy for this project was not randomized or standardized. The key sampling criteria were diversity and representativeness. Our objective was to represent the full range of stakeholders--managers, practitioners, regulatory agency representatives, technology developers, and public interest groups--in our sample. Informed participants helped identify potential respondents. A list of 31 respondents who were interviewed for the project are attached as Appendix C.

\subsection{Analytic Method}

Once the data were collected, the dimensions valued by respondents were identified through analytic coding--the process of categorizing and sorting the data. The coding was a two-phase process. In the initial coding phase, the data were sorted into discrete categories for which we developed conceptual labels that described the values and costs reported by respondents. For example, in this first round of sorting, many respondents talked about "improving the project." We used this as a conceptual label for all those values related to making the project better. The responses to each question were analyzed individually using these conceptual labels to identify the values reported by each respondent. After the individual questions were analyzed, the values were then compared across questions.

The conceptual labels developed in the first phase constitute the dimensions of value from which the indicators were developed in the second phase of focused coding. During this phase, the value dimensions (the conceptual labels) were examined for similarities and differences, which often resulted in a re-sorting of the components of the value dimensions. Following this second coding, individual indicators were developed that capture the value dimension in a way that can be measured. For example, the values included in the dimension of "improving the project" were incorporated into indicators such as "project efficiency," "cost avoidance," and "decision acceptability," all of which were components of the original value dimension. The final set of indicators are not necessarily mutually exclusive in that similar value dimensions may fit into more than one conceptual category.

At this point we re-visited the public involvemient literature to see if the major dimensions of public involvement were adequately represented in the selected indicators. Stakeholder 
accessibility to decision making was not revealed through the interviews although it is emphasized in the literature. It may be that this was not an issue for respondents because they had secured access through their successful participation. Accessibility is included as a draft indicator but should be tested through further interviews with public involvement participants.

Finally, potential metrics for each indicator were identified in order to further validate the indicators in future work. Three sources informed the construction of the metrics: (1) the public involvement literature; (2) interview data; and (3) expert judgment and experience. The list of metrics provided for each indicator is not meant to be exhaustive but to provide examples of possible ways that the indicators can be measured.

\subsection{PROTOTYPE INDICATORS}

As described above, a series of prototype indicators was developed to reflect the literature and the interview responses. When respondents talk about what is valuable to them, they use either specific and unique examples-." then manager $X$ and regulator $Y$ stopped talking to each other until we brought in a facilitator for each meeting"--or conceptual ideas--"having people with lots of different ideas is important." These specific and abstract dimensions were operationalized into "indicators" which can be measured through observation (and counting) of specific behaviors. For convenience, these indicators were divided into three different categories:

- process indicators that focus on the dimensions of value found in the procedures and processes used in the public involvement effort;

- outcome indicators that focus on the dimensions of value found in the outcomes of the public involvement effort; and

- cost indicators which describe the direct and indirect costs of the public involvement effort.

Each of the prototype indicators is described briefly in the chart below. Following the description is a summary of the interview responses about this dimension of value and indicator. Potential metrics are provided, although it should be recognized the proposed metrics provided include a mix of qualitative and quantitative measurement. Procedures for collecting data on each of the metrics will need to be developed for further testing. 


\subsection{Prototype Process Indicators}

\begin{tabular}{|c|c|}
\hline PROTOTYPE INDICATOR & POTENTIAL METRICS \\
\hline $\begin{array}{l}\text { (1) Accessibility to Decision Making } \\
\text { Process } \\
\text { The ability to participate in any given public } \\
\text { involvement process is dependent on several } \\
\text { variables which can be grouped together as } \\
\text { accessibility issues. These variables } \\
\text { emphasize decision makers willingness to } \\
\text { meaningfully involve stakeholders in } \\
\text { decision processes. This issue was not } \\
\text { commonly mentioned by respondents } \\
\text { although the literature on public involvement } \\
\text { considers it fundamental. }\end{array}$ & $\begin{array}{l}\text { - public input options considered during } \\
\text { strategic planning } \\
\text { - public involved early in decision process } \\
\text { public has ability to influence decision } \\
\text { process (problem definition, alternatives, } \\
\text { etć.) }\end{array}$ \\
\hline $\begin{array}{l}\text { (2) Diversity of Views Represented in } \\
\text { Public Involvement Process } \\
\text { The organization and maintenance of any } \\
\text { public involvement program depends on the } \\
\text { identification and selection of participants } \\
\text { who represent the range of public interests, } \\
\text { positions, and values. Almost all } \\
\text { respondents reported that the diversity of } \\
\text { views represented not only the community } \\
\text { and its interests, but enhanced and improved } \\
\text { discussion. }\end{array}$ & $\begin{array}{l}\text { - number of participants } \\
\text { - types of participants } \\
\text { - official invitees } \\
\text { - unofficial attendees } \\
\text { returnees } \\
\text { - minutes of meetings (views expressed) } \\
\text { - time of meeting(s) }\end{array}$ \\
\hline $\begin{array}{l}\text { (3) Opportunities for Participation } \\
\text { While public involvement participants bring } \\
\text { their own needs and desires to the process, } \\
\text { they all expect to participate in the process in } \\
\text { some meaningful way. Respondents } \\
\text { reported that participation provided the } \\
\text { opportunity to voice their concerns and } \\
\text { views not only to the decision makers, but to } \\
\text { other participants as well. }\end{array}$ & $\begin{array}{l}\text { - comment periods, length and number } \\
\text { - question \& answer periods, length and } \\
\text { number } \\
\text { - comments, length and frequency } \\
\text { - exchange between/among participants } \\
\text { input to agenda } \\
\text { - explanations of procedures } \\
\text { - opportunities to evaluate process(es) } \\
\text { - decision makers present at meetings } \\
\text { feedback after input }\end{array}$ \\
\hline
\end{tabular}




\begin{tabular}{|c|c|}
\hline PROTOTYPE INDICATOR & POTENTIAL METRICS \\
\hline $\begin{array}{l}\text { (4) Integration of Concerns } \\
\text { Public involvement is enhanced for most } \\
\text { participants by the identification and } \\
\text { integration of stakeholder concerns., } \\
\text { "Getting all the issues on the table," } \\
\text { "showing respect for our point of view," and } \\
\text { "improving and guiding" the project were all } \\
\text { common refrains from respondents about the } \\
\text { value of identifying stakeholder concerns. } \\
\text { "Affecting the test planis," "prioritizing } \\
\text { project activities," and "providing vision and } \\
\text { direction" were common responses of how } \\
\text { stakeholder concerns were integrated into } \\
\text { project activities. Interviewees from all } \\
\text { three programs were particularly satisfied } \\
\text { with the agency's willingness to hear and } \\
\text { respond to their concerns. }\end{array}$ & $\begin{array}{l}\text { - stakeholder "hot spots" identified } \\
\text { - discussion of stakeholder-identified } \\
\text { issues } \\
\text { - changes in or concurrence with problem } \\
\text { definition } \\
\text { - changes/additions to or concurrence with } \\
\text { considered alternatives } \\
\text { - action(s) taken in response to stakeholder } \\
\text { concern } \\
\text { - reprioritization of program goals }\end{array}$ \\
\hline $\begin{array}{l}\text { (5) Information Exchange } \\
\text { The two-way exchange of information is at } \\
\text { the heart of public involvement programs. } \\
\text { Every respondent reported that the } \\
\text { process(es) they were involved in allowed } \\
\text { information to flow and understanding to } \\
\text { develop on both sides of the table. } \\
\text { Information of value to participants included } \\
\text { technical, regulatory, and public } \\
\text { acceptability. }\end{array}$ & $\begin{array}{l}\text { - availability of documents and other } \\
\text { materials (from all stakeholders) } \\
\text { - clarity of information } \\
\text { - documents and materials translated as } \\
\text { necessary } \\
\text { - number of meetings, exchanges } \\
\text { - number of public presentations } \\
\text { - number of workshops }\end{array}$ \\
\hline
\end{tabular}




\subsection{Prototype Outcome Indicators}

\begin{tabular}{|c|c|}
\hline PROTOTYPE INDICATOR & POTENTIAL METRICS \\
\hline \multicolumn{2}{|l|}{ (1) Project Efficiency } \\
\hline $\begin{array}{l}\text { Public involvement is frequently claimed to } \\
\text { reduce the amount of time required to } \\
\text { complete a project. Public involvement } \\
\text { activities are likely to add time "up front," } \\
\text { especially in identifying stakeholders, } \\
\text { educating participants about public } \\
\text { involvement, and developing procedures that } \\
\text { identify and integrate stakeholder concerns. } \\
\text { Respondents claimed that regardless of these } \\
\text { additional time requirements, time was saved } \\
\text { on their projects in terms of faster decisions, } \\
\text { fewer work stoppages, fewer lawsuits, and } \\
\text { quicker implementation of decisions. }\end{array}$ & $\begin{array}{l}\text { - percentage of decisions approved } \\
\text { - percentage of deadlines met } \\
\text { - ratio of actual to anticipated length of } \\
\text { decision process } \\
\text { - ratio of actual to anticipated decision date } \\
\text { - duration of time between decision and } \\
\text { implementation action } \\
\text { - comparison with similar project conducted } \\
\text { without public involvement } \\
\text { - number of "start overs" (decisions required } \\
\text { to be re-addressed) }\end{array}$ \\
\hline \multicolumn{2}{|l|}{ (2) Cost Avoidance } \\
\hline $\begin{array}{l}\text { Many of the project "savings" reported in } \\
\text { public involvement efforts are actually an } \\
\text { avoidance of potential costs. These avoided } \\
\text { costs are notoriously difficult to measure and } \\
\text { document. However, respondents perceive } \\
\text { these "savings" to be substantial in some } \\
\text { cases and important in all projects. } \\
\text { Respondents reported that typical "savings" } \\
\text { include avoided litigation and additional } \\
\text { studies or investigations, regulatory } \\
\text { streamlining, and acceleration of the } \\
\text { decision process. }\end{array}$ & $\begin{array}{l}\text { - ratio of actual to anticipated costs } \\
\text { - ratio of actual to anticipated length of } \\
\text { decision process } \\
\text { - litigation avoided (number, potential cost) } \\
\text { - scheduled project components avoided } \\
\text { (number, potential cost) } \\
\text { - altered time lines } \\
\text { - ratio of selected alternative cost to original } \\
\text { alternative cost (less expensive alternative } \\
\text { identified) }\end{array}$ \\
\hline \multicolumn{2}{|l|}{ (3) Project/Decision Acceptability } \\
\hline $\begin{array}{l}\text { Underlying all of public involvement is the } \\
\text { desire to improve chances that decisions will } \\
\text { be acceptable to the widest range of } \\
\text { stakeholders, including agency staff. The } \\
\text { majority of respondents reported that the } \\
\text { public involvement process they were } \\
\text { involved in enhanced project acceptability. } \\
\text { From a manager's perspective this can mean } \\
\text { avoiding unanticipated conflict in the future, } \\
\text { accelerating regulatory processes, and } \\
\text { justifying continued funding. Other } \\
\text { stakeholders are likely to view acceptability } \\
\text { as the point or goal of all public involvement } \\
\text { efforts. }\end{array}$ & $\begin{array}{l}\text { - amount of work stoppage or delays due to } \\
\text { stakeholder protest } \\
\text { - litigation } \\
\text { - implementation of decision(s) } \\
\text { - regulatory approval } \\
\text { - favorable media coverage } \\
\text { - implementation funding } \\
\text { ratio of negative to positive stakeholder } \\
\text { comments }\end{array}$ \\
\hline
\end{tabular}




\begin{tabular}{|c|c|}
\hline PROTOTYPE INDICATOR & POTENTIAL METRICS \\
\hline $\begin{array}{l}\text { (4) Mutual Learning } \\
\text { Learning is the supposed outcome of } \\
\text { education as a process and mutual learning } \\
\text { occurs when all stakeholders learn from their } \\
\text { participation in public involvement efforts. } \\
\text { Mutual learning suggests that all } \\
\text { stakeholders see themselves as responsible } \\
\text { for finding a solution, rather than defending } \\
\text { a particular cause or agency. Respondents } \\
\text { told us that when stakeholders put their } \\
\text { personal agendas aside, focused on the } \\
\text { problem(s) at hand, and worked together to } \\
\text { develop solutions, mutual learning was } \\
\text { occurring. }\end{array}$ & $\begin{array}{l}\text { - number of concessions or compromises } \\
\text { - defining self as part of problem and problem } \\
\text { solving } \\
\text { - changes in position } \\
\text { - representation of other's position(s) } \\
\text {. }\end{array}$ \\
\hline $\begin{array}{l}\text { (5) Mutual Respect } \\
\text { Participation in public involvement } \\
\text { processes allows stakeholders to work, talk, } \\
\text { and solve problems with individuals who are } \\
\text { often perceived as the "enemy." If } \\
\text { successful, this opportunity results in an } \\
\text { increase in respect for other people, their } \\
\text { perspectives, and positions they take on } \\
\text { issues. Respondents report that other } \\
\text { participants are usually "de-demonized;" } \\
\text { they are no longer seen as the enemy. For } \\
\text { mangers, this often translates into viewing } \\
\text { the input of stakeholders as valuable to } \\
\text { resolving problems. Other stakeholders } \\
\text { begin to see agency staff as individuals they } \\
\text { can talk with and who listen to concerns. }\end{array}$ & $\begin{array}{l}\text { - character of verbal exchanges } \\
\text { access to individuals } \\
\text { - contacts between stakeholders } \\
\text { contacts between stakeholders and agency } \\
\text { representatives } \\
\text { - continued participation }\end{array}$ \\
\hline
\end{tabular}




\subsection{Prototype Direct Cost Indicators}

\section{DIRECT COSTS}

Direct costs can usually be measured through traditional accounting practices once the indicators have been selected.

(1) Staff labor or reimbursement for participation

(2) Time (3)

(3) Facilitation services

(4) Facilities

(5) Materials

(6) Travel

(7) Specialists/experts

\section{POTENTIAL METRICS}

Metrics of direct cost indicator are likely to be traditional accounting designations of costs.

time required for preparation

- time required for participation

- timé required for follow-up

- meeting room

- meals

- audio-visual

- preparation of materials

- printing of materials

- mailing (or other distribution) of materials 


\subsection{Prototype Indirect Cost Indicators}

\begin{tabular}{|c|c|}
\hline $\begin{array}{l}\text { PROTOTYPE INDIRECT COSTS } \\
\text { Indirect costs cannot usually be measured } \\
\text { through traditional accounting practices, } \\
\text { although participants are likely to recognize } \\
\text { that they are "paying" these expenses. }\end{array}$ & $\begin{array}{l}\text { POTENTIAL METRICS OF INDIRECT } \\
\text { COSTS }\end{array}$ \\
\hline $\begin{array}{l}\text { (1) Time } \\
\text { a. cumulative: many stakeholders participate } \\
\text { in more than one public involvement } \\
\text { process. Their sense of time requirements } \\
\text { may reflect the number of projects they } \\
\text { participate in or a ratio of the current } \\
\text { project to total projects time commitment. } \\
\text { b. perceptions: many stakeholders perceive } \\
\text { their public involvement activities as } \\
\text { painful or distasteful. This may be } \\
\text { reflected in a distortion of the memory of } \\
\text { how much time is required for public } \\
\text { involvement participation. } \\
\text { c. attention: decision making efforts are } \\
\text { frequently stretched out over many } \\
\text { months, with actual public involvement } \\
\text { required only sporadically. However, } \\
\text { stakeholders are required to attend to the } \\
\text { progress of the decision making which } \\
\text { may be reflected in a perception that time } \\
\text { requirements are heavy. }\end{array}$ & $\begin{array}{l}\text { - number of projects involved in } \\
\text { ratio of current project time to total project } \\
\text { time commitments } \\
\text { ratió of current project time commitment to } \\
\text { total length of project }\end{array}$ \\
\hline \multicolumn{2}{|l|}{ (2) Opportunity } \\
\hline $\begin{array}{l}\text { Participation in, funding of, and commitment } \\
\text { to public involvement efforts often requires } \\
\text { foregoing other resource-dependent } \\
\text { activities. These "lost opportunity" costs are } \\
\text { notoriously difficult to measure, but the } \\
\text { consequences are apparent to most } \\
\text { stakeholders and agencies. }\end{array}$ & $\begin{array}{l}\text { - number of foregone opportunities to } \\
\text { participate in other public involvement } \\
\text { efforts } \\
\text { - number of foregone opportunities to sponsor } \\
\text { other public involvement efforts } \\
\text { - number of foregone opportunities to } \\
\text { participate in other activities }\end{array}$ \\
\hline
\end{tabular}




\begin{tabular}{|c|c|}
\hline PROTOTYPE INDICATOR & POTEN̦TIAL METRICS \\
\hline \multicolumn{2}{|l|}{ (3) Authority and Influence } \\
\hline $\begin{array}{l}\text { Participation in public involvement efforts is } \\
\text { perceived by some stakeholders as a } \\
\text { diminution of their decision making } \\
\text { authority or influence. Respondents told us } \\
\text { that they not only feared a loss of their } \\
\text { decision making authority, but also a loss of } \\
\text { credibility within their organization, a fear } \\
\text { that information they shared would be used } \\
\text { against them in the future, and peer pressure } \\
\text { in the public involvement effort that was } \\
\text { difficult to justify outside the effort. }\end{array}$ & $\begin{array}{l}\text { - amount of public involvement in subsequent } \\
\text { activities } \\
\text { continuing participation } \\
\text { - time between report and implementation } \\
\text { level and number of managers and/or } \\
\text { officials participating } \\
\quad \therefore\end{array}$ \\
\hline \multicolumn{2}{|l|}{ (4) Emotional } \\
\hline $\begin{array}{l}\text { Many respondents reported that they paid a } \\
\text { heavy emotional cost for participation in } \\
\text { public involvement activities. They report } \\
\text { personal verbal attacks, demands that cannot } \\
\text { be met, lack of institutional support, and } \\
\text { general frustration as common side effects of } \\
\text { public involvement. }\end{array}$ & $\begin{array}{l}\text { - continued participation } \\
\text { number and type of verbal comments } \\
\text { ratio of participants to non participants at } \\
\text { meetings and public hearings }\end{array}$ \\
\hline
\end{tabular}




\subsection{DISCUSSION OF THE FINDINGS}

While this research project was designed to develop a series of prototype indicators of value and cost added through public involvement, several findings from the research methods, interviews, and analysis are worth noting.

- Public involvement participants were able to articulate specific dimensions of value, both positive and negative, brought to a project by public involvement activities. However, we only spoke with participants in effective programs and it may be possible that respondents from less effective efforts may have difficulty in identifying dimensions of positive value or may reveal somewhat different dimensions of value.

$\therefore$

- The protocol was designed to ask participants-about value dimensions in several different ways. For all but the most articulate and organized respondents, this method proved fruitful and additional questions usually continued to generate new information about valued dimensions of public involvement. For those especially articulate respondents, however, the protocol was repetitious and was shortened to avoid alienating the interviewee.

- No participants discussed the value of accessibility to decision making although this issue is considered fundamental in the existing literature. This may be due to the successful nature of the participants' access to programs which they considered effective. Or, people who have been actively involved for a longer time and with more projects may articulate different values. We may find that participants with less effective access or in less successful programs value and articulate concerns about accessibility (or lack thereof) to public involvement.

- Almost without exception, respondents identified having a wide diversity of views represented in the public involvement process as valuable and important to them. Almost all respondents also reported that accommodating the different values and needs of this diverse group of stakeholders was difficult, if not impossible, to accomplish within the public involvement effort. Integrating input from stakeholders was attempted through allowing stakeholders to change the agenda as required, flexibility in defining problems, providing feedback on the use of input, and having stakeholders evaluate the public involvement effort.

- Several respondents discussed project "savings" resulting from public involvement programs. These "savings" typically take the form of costs avoided such as avoided litigation, additional investigations, and program components. When asked to assess the monetary value of these avoided costs, respondents typically provided large, rounded-off figures such as $\$ 100$ million or $\$ 45$ million, which suggests that the "savings" are estimates. While avoiding litigation, new research, and schedule project components can save a large amount of money, these "savings" are hypothetical in nature. While the perception of stakeholders "saving" large amounts of money should not be 'denied, relying on these numbers for indicators of value added through public involvement poses both ethical and methodological questions. For example, how can one assess the amount of money saved by avoiding a hypothetical lawsuit on a hypothetical issue brought by hypothetical stakeholders? These types of "savings" can only be evaluated through a rigorous and comparative evaluation of completed projects.

- Measuring the direct costs of public involvement should be relatively easy using traditional accounting practices. Indicators of direct costs also serve as metrics. One indicator of cost that will be interesting to track is change in costs over time. As public 
involvement becomes more efficient, costs should decrease or, at least, not increase for projects of similar magnitude. These changes will need to.be measured against a "baseline" of current costs. Measuring indirect costs will present problems similar to measuring process and outcome dimensions. This does not mean that indirect costs should not be tracked. Respondents' perceptions that they are "paying" the price for participating in public involvement efforts are often indicated in how they feel about indirect costs such as lost opportunity, loss of authority and influence, and emotional wear and tear.

- When asked how much time is required to participate in public involvement efforts, most respondents believe that their time commitment is quite large. When pressed to document the time spent on preparation, participation, and follow-up, however, the tallies turned out to be quite modest. We try to capture this discrepancy between actual amount of time and perceived amount of time in the indicators of indirect costs of cumulative time, perceptions of time, and length of attention required (as described in Section 5.4). Actual time commitment to public involvement needs to be tracked carefully and completely while exploration of these indirect time costs proceeds to determine what contributes to the idea that public involvement "takes a lot of time."

\subsection{CONCLUSIONS}

\subsection{Next Steps}

This first step of the effort to develop prototype indicators of the value added through public involvement identified those dimensions of public involvement that were valued, either positively or negatively, by participants in three different public involvement efforts sponsored by the Department of Energy. The dimensions were operationalized into indicators which could be measured and potential metrics for such measurement. However, this is only the first step in a series of steps that are necessary to develop useful indicators.

The next step is to take these prototype indicators back to a sample of the initial respondents to determine whether these indicators truly capture the dimensions of value they identified in their interviews. Validation of the indicators will also benefit from talking with public involvement participants beyond these three projects, outside of DOE, in different stages, and with more varied outcomes. Participants from different types of public involvement efforts are likely to : accept the proposed indicators but will probably suggest others that reflect their own programs and experiences. The indicators can be refined using all validation sources.

After this validation and refinement process, the indicators will need to be tested in ongoing and completed public involvement programs. Procedures for obtaining data on the metrics will need to be developed. And then, baseline data collection will be necessary. The indicators should be tested on programs that are considered successful as well as unsuccessful. If possible, the indicators should also be tested on public involvement efforts sponsored by DOE and other federal agencies such as the Department of Defense as well as state-level efforts such as those sponsored by the Washington State Department of Ecology. It is only through testing the indicators on a wide array of programs that their general usefulness will be assessed.

\subsection{Using the Prototype Indicators at Hanford and the Pacific Northwest Laboratories (PNL)}

As discussed above, the draft indicators will need to be validated, refined, and tested on a wide array of public involvement efforts and with a range of stakeholders. However, in the short term, the indicators can be used as a discussion point with Hanford and PNL managers currently 
sponsoring public involvement activities as well as those managers who have yet to do so. Hanford and PNL managers who sponsor or participate in public involvement activities can help in the validation of the indicators. They can be asked to review this report and to provide input based on their own positive and negative experiences. These managers may also have pragmatic suggestions for metrics for the indicators. Their participation in any future testing phases can also be solicited at this point.

For those Hanford and PNL managers who have yet to sponsor or participate in public involvement activities, the prototype indicators can be used to discuss common costs and benefits of using public involvement to manage public input to benefit projects. The indicators are likely to identify many of their fears of participation, particularly the indirect costs and time commitments. The discussions can also be used to validate the prototype indicators and to ensure that no major dimensions have been overlooked in this process. The indicators (and report) can begin an iterative discussion process with these managers as they begin to think about public involvement.

The prototype indicators can also be used in any future public involvement training for Hanford and PNL staff. The indicators can provide a summary of the process and outcome requirements that are components of an effective public involvement effort. Even in their draft form, the indicators provide a starting point for discussion that can involve people in thinking about ways to measure the value and costs added through public involvement. 


\section{APPENDIX A \\ References}

Cupps, D. S. 1977. "Emerging Problems of Citizen Participation." Citizen Participation Sept./Oct.: 478-485.

Fiorino, D. J. 1990. "Citizen Participation and Environmental Risk: A Survey of Institutional Mechanisms." Science, Technology, \& Human Values 15 (2): 226-243.

Gericke, K. L., and J. Sullivan. 1994. "Public Participation and Appeals of Forest Service Plans: An Empirical Examination." Society and Natural Resources 7: 125-135.

Goldenberg, S., and J. S. Frideres. 1986. "Measuring the Effects of Public Participation Programs." Environmental Impact Assessment Review 6: 273-281.

Nelkin, D. 1984. "Science and Technology : Policy and the Democratic Process" Pp. 18-39 in Citizen Participation in Science Policy, ed., J. C. Petersen. Amherst: The University of Massachusetts Press.

Rosener, J. B. 1982. "Making Bureaucrats Responsive: A Study of the Impact of Citizen Participation and Staff Recommendations on Regulatory Decision Making." Public Administration Review . 42: 339-345.

Rosener, J. 1981. "User-Oriented Evaluation: New Way to View Citizen Participation." The Journal of Applied Behavioral Science 17: 583-596.

Rosener, J. 1978. "Citizen Participation: Can We Measure its Effectiveness." Public Administration Review Sept./Oct.: 457-463.

Sewell, W. R., and S. D. Philips. 1978. "Models for the Evaluation of Public Participation Programmes." Natural Resource Journal 19:337-358.

Steel, B. S., P. List, and B. Shindler. 1994. "Conflicting Values About Federal Forests: A Comparison of National and Oregon Publics." Society and Natural Resources 7: 137-153.

Young, C., G. Williams, and M. Goldberg. 1993. Evaluating the Effectiveness of Public Meetings and Workshops: A New Approach for Improving DOE Public Involvement. Report ANL/EAIS/TM-100 prepared by Argonne National Laboratory for the United States Department of Energy. 


\section{APPENDIX B}

Protocol

Background information:

organization

job responsibility

job tenure (how long on the job)

Have you had any prior experience with public involvement? if so, describe briefly

note gender

1. How were you involved in the FSUWG, TWTF, or VOC-Arid public involvement effort?

- What was your role?

- How and why did you get involved?

- Can you estimate the resources/time you (your organization) spent on public involvement for this project?

2 When you began this project, what did you want public involvement [your participation] to accomplish? What did you expect it to accomplish?

- for yourself?

- the project?

- for the organization?

- for the community?

3. How did you expect the process to fulfill these expectations?

- How did you expect public involvement to affect your relationship with agencies and other stakeholders? (who and how)

- How well did the public involvement process meet your expectations?

4. In your view, what did the public involvement process [your participation] ADD that was beneficial (useful, valuable):

- to the project

- to you personally

- to your organization

- to the community

- other

5 What were the disadvantages (costs) of the public involvement effort?

- to the project

- to you personally

- to your organization

- to the community

- other

6. Overall, what difference do you think the public involvement process/your participation made to:

- project success (what does that mean to you)

- public acceptability

- good decision making

- efficiency (saved time, money, effort) 
7. How would you assess the benefits of the public involvement effort relative to the costs? (i.e., was it worth it and why?)

8. Have you measured or documented the benefits or costs of public involvement?

- if so, what measures or documentation are used? Can we get a copy of this information?

- if not, can you think of ways you might be able to measure or document the costs and benefits?

9. In what ways, if any, do you think the public involvement effort/your participation:

- changed the definition of the problem

- helped implement a decision

- changed milestones

- impacted your budget

- affected public acceptability

- changed you--your understanding, positions, feelings

- changed the relationship between your organization and the project stakeholders

10. How could the public involvement process have been improved?

- by the project team

- by the stakeholders

11. (For project managers/pi specialists) What are you doing about public involvement on your other projects?

- How have you incorporated public involvement into new programs?

- If NO, why not

- If Yes, was your approach/pi effort on this project influenced by your experience with the FSUWG, TWTF, VOC-Arid project? How?

12. Overall, what do you think public involvement brings to decision-making processes?

- What would be lost if there were no public involvement?

- What is your bottom line message about public involvement?

That's all the questions I have. What questions do you have for me? Are you interested in receiving a copy of the report? 


\title{
APPENDIX C \\ List of Respondents
}

\author{
NAME \\ John J. Barich \\ Theresa Bergman \\ Mary Lou Blazek \\ Tom Brouns \\ Kathy Criddle \\ Paul Day \\ Greg deBruler \\ Bill Dixon \\ Tyler Gilmore \\ Mike Grainey \\ Pat Hale \\ Kim Keogler \\ Joe King \\ John Lindsay \\ Todd Martin \\ Toby Michellina \\ Bill Mitchell \\ Sandi Murdock \\ Kathy Niesen \\ Gretchen McCabe \\ Nancy Pearson \\ Todd Peterson \\ Max Powers \\ Gorden Rogers \\ Cynthia Sarthou \\ Pat Serie \\ Roger Stanley \\ Steve Stein \\ W.A. Wallace
}

\author{
AFEILIATION \\ Environmental Protection Agency \\ Westinghouse Hanford \\ Oregon Department of Ecology \\ Pacific Northwest Laboratory \\ Lower Columbia Basin Audubon Society \\ Environmental Protection Agency \\ Columbia River United \\ Westinghouse Hanford \\ Pacific Northwest Laboratory \\ Oregon Department o Ecology \\ Westinghouse Hanford \\ Bechtel \\ City of Richland \\ TRIDEC (Tri-Cities Industrial Development \\ Council) \\ HEAL (Hanford Education Action League) \\ Washington Department of Ecology \\ Nuclear Safety Campaign \\ Westinghouse Hanford \\ Environmental Issues Management \\ Battelle Columbus \\ League of Women Voters \\ Battelle Columbus \\ Washington Department of Ecology \\ Tri-Cities Technical Council \\ Heart of America Northwest \\ Environmental Issues Management \\ Washington Department of Ecology \\ Pacific Northwest Laboratory \\ CH2M Hill
}

